\title{
Helsepersonell som etterlatte ved selvmord
}

\author{
Ved Onja Grad
}

Når en pasient som er i behandling tar sitt eget liv, er det en tragisk og opprivende hendelse ikke bare for familien, men også for hans/hennes behandlere. I denne artikkelen skal vi se naermere på hvordan profesjonelle hjelpere som blir etterlatte på denne måten føler det, og hvordan de reagerer under slike vanskelige omstendigheter. Vi skal også diskutere mulige måter å gi støtte til behandlere på når en pasient tar sitt eget liv.

Alle som arbeider i den vanskelige og risikofylte verden som deprimerte og suicidale pasienter befinner seg i, vet fra egen personlig erfaring hvilken katastrofe det er når en pasient tar sitt eget liv. Mer enn en tredel av alt helsepersonell som arbeider med mennesker i krise, vil oppleve selvmord hos en pasient i løpet av de første årene i sin karriere. Resten vil oppleve det samme, men noe senere.

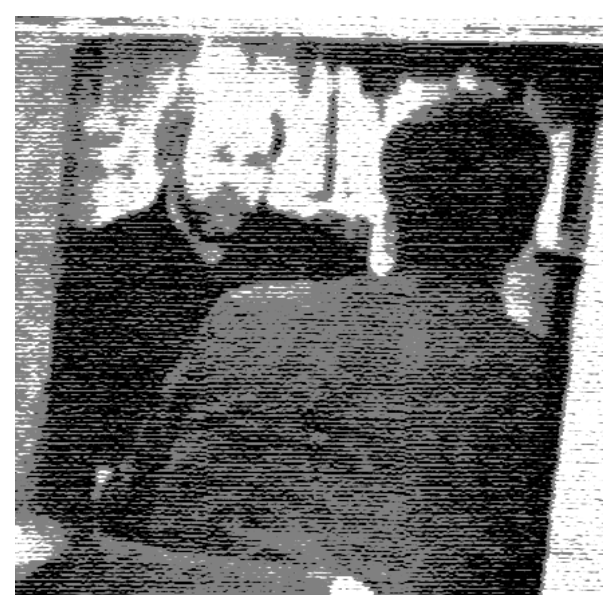

Som Brown (1987) har sagt: Det er bare to typer behandlere: de som allerede har opplevd at en av deres pasienter har tatt sitt liv, og de som kommer til å gjøre det. Intense og ubehagelige følelser vekkes når vi tenker tilbake på hvordan det opplevdes å høre om vår pasient som hadde tatt sitt liv. Det skjedde uventet selv om vi kanskje lenge hadde tenkt på muligheten av selvmord, eller hadde vært redde for at det skulle skje. Den første reaksjonen var derfor sjokk og kanskje benekting av kjensgjerningene. Kanskje informasjonen var feilaktig? Siden kom angsten, det redselsfulle, skyldf $\varnothing$ lelsen, sinnet og følelse av tristhet og hjelpeløshet - både profesjonelt og personlig - fordi vi som medmennesker ikke skulle være i stand til å forebygge dette meningsl $\varnothing$ se og tragiske. Vi stilte oss spørsmål om vår egen profesjonalitet, vår ansvarlighet og vår kompetanse. Med en mild overdrivelse kunne vi kalle oss selv "overlevende" (survivors) etter selvmord.

\section{Å vaere etterlatt ved selvmord}

A være etterlatt (eng. suicide survivor) etter selvmord innebærer å stå i et nært forhold til noen som har tatt sitt eget liv, gjennom slektskap, vennskap, kollegialt forhold eller gjennom et pasient/behandlerforhold. Frem til 1960 forelå nesten ingen publikasjoner om emnet etterlatte ved selvmord, og ingen spesielle hjelpetiltak ble tilbudt de etterlatte (Wertheimer 1997). All oppmerksomhet ble rettet mot dem som hadde gjort selvmord eller forsøkt selvmord. Da man begynte å gjøre såkalte psykologiske autopsier i en studie i Los Angeles Suicide Prevention Center (Litman 1970), la man merke til at intervjuene, som primært var rettet mot å samle informasjon om den avd $\varnothing \mathrm{de}$, i seg selv hadde en tydelig terapeutisk effekt på de etterlatte som deltok i intervjuet.

\section{Individuelle sorgprosesser}

Som etter andre d $\varnothing$ dsfall vil sorgreaksjonene etter selvmord følge fire hovedfaser: sjokkfasen, reaksjons- eller desperasjonsfasen, hjelpeløshets- eller disorganiseringsfasen og til slutt reorganiseringsfasen (Bowlby 1991). Men hvis vi skal hjelpe etterlatte ved selvmord, må vi være klar over at det ikke eksisterer noen skjematiske sorgreaksjoner etter selvmord, alle går igjennom det på sin egen individuelle måte. Når en pasient tar sitt eget liv, vil den etterlatte terapeuten ofte ha de samme typene reaksjoner som andre som stod avdøde nær.

\section{Når behandlere blir etterlatte}

Det er få andre hendelser som kan fremkalle slik en opplevelse av å ha sviktet og gi opphav til slik en skyldfølelse hos hjelperen, som pasientens selvmord (Grad 1996). Når dødsårsaken er hjertekarlidelse eller annen dødelig sykdom, blir det gjerne opplevd som uunngåelig og naturlig, eller til og med som en ønsket lettelse etter et langvarig sykeleie. Selvmord blir derimot nesten alltid betraktet som en hendelse vi skulle ha vært i stand til å forebygge. Vi skulle ha gjort en bedre risikovurdering av den selvmordsnære pasienten, vi skulle ha tatt hans suicidale signaler mer alvorlig, vi skulle tatt bedre kontroll over situasjonen, f.eks. gjennom innleggelse (Lloyd 1995).

Selv om det å arbeide med selvmordsnære pasienter innebærer risiko for selvmord hos pasienten, mener Litman (1965) at terapeuter ikke reagerer særlig annerledes enn andre etterlatte ved selvmord. Hvor sterk reaksjonen blir, ser ut til å henge sammen med flere faktorer:

- Hvor langvarig og dyptgående forholdet mellom pasient og terapeut var.

- Hvor alvorlig risikoen for selvmord var.

- Hva den terapeutiske setting (sykehus eller ambulant behandling) var.

- Hvorvidt behandleren fikk jevnlig veiledning eller ingen veiledning.

- Om terapeuten var alene om behandlingsansvaret eller om det var flere teammedlemmer som delte på dette.

- Hva som var behandlerens forklaring på pasientens selvmord.

- Om behandleren var meget erfaren eller nybegynner.

- I hvilken livsfase både behandleren og pasienten var.

- Hvilke tidligere erfaringer behandler hadde med egne tap eller sorgopplevelser.

- Hvilket teoretisk, klinisk og filosofisk ståsted til selvmord terapeuten hadde.

- Terapeutens kjønn og personlighet.

Mange av følelsene handler om terapeutens egen profesjonalitet. Terapeuten kan føle seg mislykket, ubrukbar og hjelpe1øs. Han opplever på en smertefull måte grensene for sin egen kunnskap og evne til å helbrede pasienter. Han kan også oppleve angst for hvilke reaksjoner pasientens etterlatte kan komme til å gi uttrykk for. 
Chemtob (1988) fant at $57 \%$ av amerikanske psykiatere rapporterte det som et personlig traume når en pasient hadde tatt sitt eget liv. I en unders $\varnothing$ kelse vi selv gjorde i Ljubljana, $\varnothing$ nsket vi å studere om terapeutene, psykiatere og kliniske psykologer ville rapportere liknende reaksjoner. Flertallet av terapeutene (Grad et al.1997) rapporterte følelser som tristhet, angst, skyldfølelse og rastløshet. Signifikant flere kvinnelige terapeuter kjente skamfølelse og skyldfølelse og følte trang til å bli trøstet. Flere av dem tvilte på sin egen profesjonelle kyndighet. Signifikant flere mannlige terapeuter fortsatte å arbeide som vanlig. Flertallet av terapeuter av begge kjønn rapporterte å ha snakket med kolleger eller veileder for å ventilere sine følelser. Når vi sammenliknet svarene fra psykoterapeuter med tilsvarende svar fra allmennleger, var det flere likhetspunkter enn forskjeller (Grad \& Zavasnik 1998). Likevel var det signifikant flere terapeuter enn allmennleger som rapporterte skyldfølelse etter pasientens selvmord, og de betrodde seg i større grad til kolleger og veiledere enn hva allmennleger rapporterte å gjøre.

\section{Hva hjelper?}

I vår undersøkelse ble terapeutene spurt om hva som hadde vært til hjelp for dem etter pasientens selvmord. Flertallet svarte at det å snakke med noen av sine nærstående hadde vært til stor hjelp (56 \%).

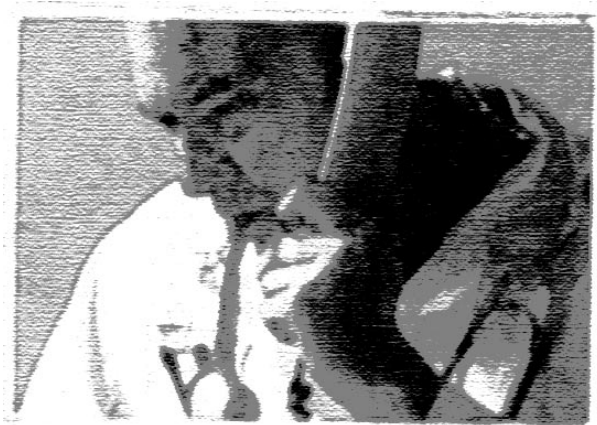

$\AA$ arbeide videre som vanlig hadde vært til hjelp for ytterligere $14 \%$, og noen få (5\%) hadde følt det som en hjelp å prøve å finne ut årsakene til selvmordet. Det å få hjelp til å snakke om egne følelser og refleksjoner etter pasientens selvmord sammen med en annen person eller i en gruppe som gir forståelse, st $\varnothing$ tte og hjelp, er en av flere mulige måter å hjelpe tera- peuten til å gjenvinne balansen på. Det er til stor hjelp om han/hun fritt kan snakke med noen som allerede har opplevd en slik hendelse, eller som erkjenner at de kan komme til å oppleve det selv i fremtiden. Noen behandlere foretrekker likevel å arbeide med dette alene og tenke igjennom hele hendelsen på egen hånd. Alle behandlere bør få muligheten til å finne sin egen personlige måte å uttrykke og forstå sine egne følelser på og ikke bli tvunget inn i en ramme som ikke passer ham/henne.

Alle institusjoner og behandlingsenheter som jevnlig er i kontakt med selvmordsnære pasienter, bør sette opp standard handlingsm $\varnothing$ nstre for tilfeller av pasienters selvmord (Grad 1996, Mehlum 1999). En slik prosedyre må være fleksibel nok til å ta vare på ulike terapeuters behov. Noe av hensikten er å hjelpe terapeuten til å redefinere sin personlige og profesjonelle rolle (Kolodny et al. 1979). Men samtidig har prosedyren en viktig funksjon i å bevisstgjøre behandlerne på det faktum at pasienter kan ta sitt eget liv, særlig når det dreier seg om de selvmordsnære pasientene som de har bestemt seg for å arbeide med.

\section{Konklusjon}

Uansett hvor mye vi fors $\varnothing$ ker å forebygge selvmord, vil selvmordet alltid være en del av den menneskelige tilværelse. Likeledes vil etterlatte ved selvmord - det være seg slektninger eller hjelpere - aldri bli en utd $\varnothing$ dd rase. På et vis kan det være trøst i å akseptere dette faktum, fordi vi blir jo etterlatte nettopp fordi vi så sterkt prøver å hjelpe pasientene og våger å være i deres nærhet. Etter hvert har kunnskapen om at etterlatte ved selvmord finnes og at de har spesielle behov, $\varnothing \mathrm{kt}$. Samtidig har tabuiseringen og stigmatiseringen av problemet avtatt. Dette har gjort det mulig å få til positive endringer. Våre kunnskaper om sorgprosesser $\varnothing$ ker, og vi vet stadig mer om hvordan vi skal hjelpe og trøste de etterlatte ved selvmord. Vi vet også at vi, behandlerne, ikke er immune mot de intense følelsene og reaksjonene som følger når pasienter tar sitt liv. Men vi vet også at det hjelper å erkjenne disse følelsene åpent og snakke om dem.
Give sorrow words; the grief that does not speak knits up

the o erwrought heart and bids it break.

W. Shakespeare, Macbeth

(Artikkelen er oversatt og bearbeidet av Lars Mehlum.)

\section{Litteraturliste}

Bowlby J. Attachment and loss, volume III. Loss: sadness and depression. Harmondsworth: Penguin, 1991

Brown $\mathrm{H}$. The impact of suicide on therapists in training. Comprehensive Psychiatry 1987; 28: 101 - 112 .

Chemtob CM, Hamada RS, Bauer G, et al. Patient`s suicides: frequency and impact on psychiatrists. American Journal of Psychiatry 1988; 145: 224-228.

Grad OT. (1996) Suicide - How to survive as a survivor. Crisis 1996; 17: 136-142.

Grad OT, Zavasnik A, Groleger U. Suicide of a patient: gender differences in bereavement reactions of therapists. Suicide and Life-Threatening Behavior 1997; Winter: 379-386

Grad OT, Zavasnik A. Emotional reactions of the therapist. In: Kosky R.J. et al. (eds.) Suicide prevention: the global context. New York: Plenum Press. 1998: 287-291.

Kolodny S, Binder R, Bronstein A, Friend RL. The working through of patient's suicide by four therapists. Suicide and Life-Threatening Behavior 1979; 9:33-46

Litman RE. When patients commit suicide. American Journal of Psychotherapy 1965; 4: 570-576.

Litman RE. Management of suicidal patients in medical practice. In Shneidman ES, Farberow NL \& Litman RE (eds.) The psychology of suicide. New York: Science House, 1970.

Lloyd, G.G. (1995). Suicide in hospital: guideliness for prevention. Journal of Royal Society of Medicine 1995; 88: 344-346.

Mehlum L. Etter selvmordet. I Mehlum L. (red). Tilbake til livet. Selvmordsforebygging i teori og praksis. Kristiansand: Høyskoleforlaget. 1999, s. 218-32.

Wertheimer A. A special scar. London: Routledge 1997.

Onja T. Grad er klinisk psykolog og førsteamanuensis ved den psykiatriske universitetsklinikken

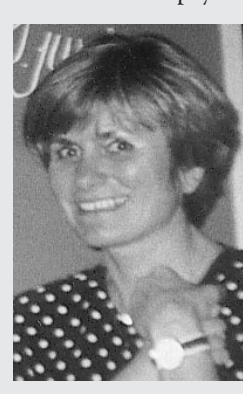
i Ljubljana. Hun arbeide både psykoterapeutisk og underviser i helsepsykologi ved det medisinske fakultet ved Universitet i Ljubljana. Hennes hovedinteressefelt er kriseintervensjon, sorgprosesser og etterlatte ved selvmord. 